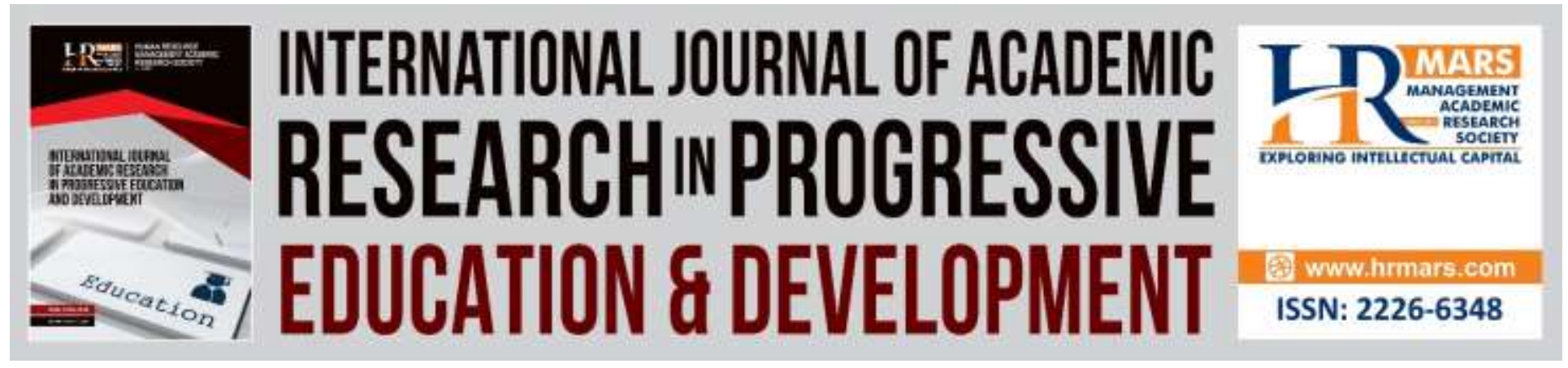

\title{
The Effectiveness of Using I-Think Maps in Teaching of Essays in General Studies Subject
}

Suppiah Nachiappan, Kalsum Binti Umar, Mohd Nazir Bin Md Zabit \& Sangkari Chandra Sehgar

To Link this Article: http://dx.doi.org/10.6007/IJARPED/v8-i3/6214

DOI: 10.6007/IJARPED/v8-i3/6214

Received: 15 May 2019, Revised: 16 June 2019, Accepted: 22 July 2019

Published Online: 29 August 2019

In-Text Citation: (Nachiappan, Umar, Zabit, \& Sehgar, 2019)

To Cite this Article: Nachiappan, S., Umar, K. B., Zabit, M. N. B. M., \& Sehgar, S. C. (2019). The Effectiveness of Using I-Think Maps in Teaching of Essays in General Studies Subject. International Journal of Academic Research in Progressive Education and Development, 8(3), 50-57.

Copyright: (c) 2019 The Author(s)

Published by Human Resource Management Academic Research Society (www.hrmars.com)

This article is published under the Creative Commons Attribution (CC BY 4.0) license. Anyone may reproduce, distribute, translate and create derivative works of this article (for both commercial and non-commercial purposes), subject to full attribution to the original publication and authors. The full terms of this license may be seen

at: http://creativecommons.org/licences/by/4.0/legalcode

Vol. 8(3) 2019, Pg. 50 - 57

http://hrmars.com/index.php/pages/detail/IJARPED

JOURNAL HOMEPAGE

Full Terms \& Conditions of access and use can be found at http://hrmars.com/index.php/pages/detail/publication-ethics 


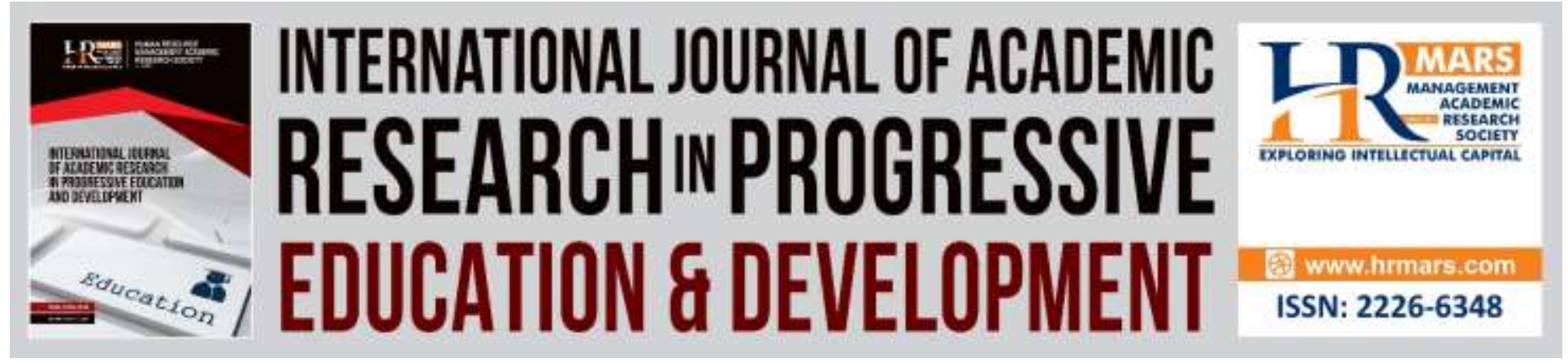

\title{
The Effectiveness of Using I-Think Maps in Teaching of Essays in General Studies Subject
}

\author{
Suppiah Nachiappan, Kalsum Binti Umar, Mohd Nazir Bin Md \\ Zabit \& Sangkari Chandra Sehgar \\ Sultan Idris Education University, Tanjung Malim, Perak. \\ Email: suppiah@fpm.upsi.edu.my, kalsum@fsk.upsi.edu.my, mohd.nazir@fppm.upsi.edu.my, \\ sangkarichandra@yahoo.com
}

\begin{abstract}
This study aims to identify the teaching methods used by the General Studies subject teachers to teach writing essays in schools. In addition, the method of using i-Think map by teachers to assist students in writing essays of General Studies subject and its effectiveness is also analyzed in this study. Qualitative approaches with the Hermeneutics method have been used in this study. A total of 14 respondents were involved in this study. Respondents were selected from among teachers who teach General Studies subject in Kinta Utara district, Perak. Then, five teachers from the number of respondents were chosen to interview. Instruments used in this study are questionnaires and interview questions. The data collected were analyzed using the Hermeneutical method. The results show that most teachers use the $i$-Think round maps to teach essay writing of General Studies subject, especially during content discussion is being conducted. The use of the i-Think round maps is also very effective in enhancing understanding and helping students to remember important contents. The implication of the study shows that the use of $\mathrm{i}-$ Think round maps can improve students' achievement on the essays writing of General Studies subject.

Keywords: I-Think Maps, Round Map, Essays of General Studies Subject.

\section{Introduction}

The Education system in Malaysia is undergoing a gradual transformation from time to time. The Government has set some aspects, particularly in education through the National Education Plan and the latest is the Malaysian Education Development Plan (MEDP) 2013-2015. The interesting aspect through MEDP is the emphasis on six aspects of the appropriate indicators as strengthening the existing system. One such element or indicator is to improve thinking skills. So every student needs to have a passion for learning how to get lifelong knowledge (KPM, 2013).
\end{abstract}


The use of i-Think maps in the process of teaching and learning is a teaching technique introduced to encourage students to think and focus more on understanding the subjects learned (Hyerle \& Yeager, 2007). Every thinking map has a thinking process adapted according to the subject or lesson unit. I-Think maps usage also help students to actively stimulate their thinking. This method also indirectly develops potential and generates creative and innovative human capital who are capable of thinking at high levels towards reaching the goal of National Education Philosophy (Rosli \& Sidek, 2013).

Thus, the effectiveness of using i-Think round maps in the essay writing of the General Studies subject was reviewed in this study. General Studies subject is a compulsory subject for the STPM students to pass in order to enter university. Students who do not pass this subject are difficult to continue their studies at Public Higher Education Institutions. This subject covers various aspects such as social science, nationhood, politics, current issues and challenges. While this subject also consists of many facts and terms that need to be memorized but are easy to understand because they are very close to the everyday lives of students as Malaysians. This subject also emphasize skills such as ability to think critically, creatively and innovatively.

One of the main sections of the paper is the essay writing section. Based on STPM syllabus from the Malaysian Examinations Council, essay writing is the part that contributes to the highest percentage of all semesters. For Semester 1, essay writing covers 50 marks of the total 80 marks. For Semester 2 this section covers 25 out of 60 marks and for Semester 3 writing essays comprising 50 out of 80 marks. This proves that marking scores for essay writing is very high. So, students must master this section for excellent grades.

\section{Problem Statement}

Mind maps is a method of remembering and jotting down effective notes to students. This method uses a few keywords to illustrate the whole important fact in a long list of essays. This method also allows one to see the image and link of knowledge simultaneously and this will facilitate readers to remember information in a short time (Buzan \& Buzan, 2013). Mind maps are ideal for summarizing information to be easier for students to remember. Notes in the form of mind maps are easier to describe and understand than a long collection of articles (Taha, 2004). So, it is easy for students to remember the contents that need to be written in an essay by drawing mind maps rather than memorizing long essays. Long reading material will cause students to be depressed and in turn causes dislike and boredom on the General Studies subject. Therefore, the features of the mind maps that enhance the creativity of students through the use of keywords, colors and symbols can facilitate the fact of being easily understood and concise.

Although the government emphasizes the mastery of General Studies subject to create brilliant human capital, the problem faced by the students is that they could not master the subject properly (Hwa, 2004). Students could not achieve good grade in General Studies subject especially in writing section. The essay writing section is the part that contributes the highest score in the General Studies subject paper. One of the main cause of pupils not being able to score well in the essay writing section is that pupils could not memorize the essential contents of various themes and facts for themes that may be tested. This is also due to the fact that students 
are not exposed to an easy method of memorizing the contents of the essays. Teachers only use traditional methods of memorizing, discussing, telling stories and many more boring methods for students. Teachers need to be wise in solving problems related to teaching and learning taught (Sabar \& Khalid, 2005).

Therefore, there is a question that what is the best way to teach the students to remember the important contents of the theme of diversity and whether the usage of i-Think round maps can help students to remember the contents of each theme taught by the teacher.

\section{Research Objectives}

In general, the objective of this study is to identify the effectiveness of the use of the i-Think round maps to improve the students' writing skills in essays of General Studies subject. Specifically, this research is carried out in order to:

i. Identify teaching methods used by General Studies teachers to teach essay writing at school.

ii. Explain methods of using i-Think maps that teachers can use to help students write essays of General Studies subject.

iii. Identify the effectiveness of using i-Think round maps for essay writing of General Studies subject.

\section{Research Questions}

i. What are the methods used by the General Studies subject teachers to teach essay writing at school?

ii. How can I-Think maps be used by teachers to help students write essays of General Studies subject?

ii. Is the use of the i-Think round maps effective in the essay writings of General Studies subject?

\section{Methodology}

This study is a descriptive study using Hermeneutic analysis. Hermeneutics analysis is a qualitative method that emphasizes the uniqueness and diversity aspects of researches. Hermeneutic analysis looks at each individual differently in a research study. Hermeneutics analysis sees each individual as unique and has its own characteristics, having their own emotions, thoughts and behaviors. Hermeneutics approach can be interpreted as an analysis of human behavior, especially to achieve a deep understanding of the process of human interaction (Loganathan, 1992; 1996). As the aspects of human behavior are psychological, the Hermeneutics analysis approach is a psychological approach. Qualitative methods are best suited for this study as this study is closely related to the psychology of human behavior.

According to Mueller (1997), Hermeneutic is an art of understanding and not as a material that has already been understood. Hermeneutics is also part of the art of thought and philosophy. Therefore, in order to interpret the knowledge of language, it is important to understand the individual's knowledge. One should remember the meaningful experience that has ever been 
passed about an event or event that affects itself directly or indirectly. Methods used in the Hermeneutical approach begin with text. It then identifies meaningful information or information in the text that is then used to generate themes or categories from a set of texts (Suppiah, 2003).

The design of this study uses the Hermeneutics analysis as a methodology used to interpret the transcript of the questionnaire to study the effectiveness of the use of the i-Think maps in the essay writing of General Studies subject. This study will be conducted in Secondary Schools in the State of Perak only. Teachers who teach General Studies subjects for Pre University students will be respondents in this study

\section{Discussion \\ Research Question 1: What are the methods used by the General Studies subject teachers to teach essay writing at school?}

\begin{tabular}{lcc}
\hline \multicolumn{1}{c}{ Teaching Methods used } & Respondent & Total Respondents \\
\hline Presentation & $\mathrm{R} 1, \mathrm{R} 2, \mathrm{R} 4$ & 3 \\
Using mind-map (i-Think) & $\mathrm{R} 5, \mathrm{R} 7, \mathrm{R} 12$, & 5 \\
& $\mathrm{R} 13, \mathrm{R} 14$ & 5 \\
Idea discussion & $\mathrm{R} 3, \mathrm{R} 6, \mathrm{R} 9, \mathrm{R} 11$, & \\
& $\mathrm{R} 13$ & 1 \\
Cooperative learning (gallery walk/ round table/ & $\mathrm{R} 10$ & 3 \\
group activities) & & 1 \\
$\begin{array}{l}\text { Exercises } \\
\text { Others (newspaper cuttings/ youtube videos / } \\
\text { mobile applications) }\end{array}$ & $\mathrm{R} 1, \mathrm{R} 2, \mathrm{R} 3$ & \\
\hline
\end{tabular}

Table 1: Methods used for teaching essays of General Studies subject

Based on Table 1, it can be concluded that most teachers use the i-Think round maps to teach the essay writing of General Studies subject. A total of five teachers from a total of 14 teachers used round maps and other i-Think maps to teach the essays of General Studies subject for students. A total of five teachers, also used the main content discussion method before the students started writing essays as a strategy to teach the essay writing of General Studies subject to students.

Next, three teachers asked the students to present their content before writing essays of General Studies subject. Once, students present their contents and are corrected by the teacher, students are asked to write essays as reinforcement exercises. A total of three teachers have stated that they provide training to students so that they can master the essay writing of General Studies subject.

In addition, only one teacher uses the cooperative learning method to teach the essay writing of General Studies subject to his/her students. The activities carried out by teachers to 
teach essays in the form of cooperative learning are like gallery walk, round table and group activities. Finally, a respondent, R8, uses other approaches such as the use of newspaper clippings, related youtube videos and mobile phone applications to teach the essay writing of General Studies subject to their students.

\section{Research Question 2: How can I-Think maps be used by teachers to help students write essays of General Studies subject?}

Respondents comprising teachers of General Studies subject stated that they can use i-Think round-maps to teach essay writing of General Studies subject in various ways. A total of five respondents indicated that the $\mathrm{i}$-Think round maps can be used during the presentation. Teachers ask students to present the contents of an essay using the i-Think round maps.

Next, four respondents stated that teachers can ask students to record important contents for the essay in the form of round maps to be used as notes. This allows students to get a brief and clearer note. Then, three teachers have explained that the round maps are suitable for discussion in the classroom. Students may be asked to discuss a topic and list important contents in the maps. Two other respondents suggested to use round maps to expand the content or ideas that the students had identified before writing a complete essay. Finally, one respondent stated that the i-Think round maps can be used as a framework. Students are asked to create a sketch in the form of $\mathrm{i}$-Think round maps before they write a complete essay.

\section{Research Question 3: Is the use of the i-Think round maps effective in the essay writing of} General Study's subject?

All respondents stated that the use of i-Think round maps are very effective in the essay writing of General Study's subject. The respondents stated that the use of i-Think round maps can improve the student's understanding of a subject learned. Additionally, the use of round maps can help students remember the contents of the essay better. Indirectly, it will help to improve student achievement on the essay writing of General Studies subject. One of the respondents also stated that the use of round maps would prevent students from feeling bored and causing students to be more focused than when using conventional methods. However, a teacher noted that although the use of round maps to write General Studies subject is effective, but the time required to draw a round map should be noted. Teachers need to ensure that students do not waste time by producing round maps.

\section{Analysis of Interview Questions}

A total of five teachers from the total number of respondents were interviewed to know their knowledge on the use of i-Think round maps to teach the essays of General Studies subject.

\section{Interview Question 1: Have Teacher Ever Attended Courses Related to the Teaching Essay Writing of General Studies Subject?}

Based on the findings of this question, it is found that only one teacher attended the course on teaching essay writing of General Studies subject but this course was held in 2008 alone. Two teachers stated that they had only attended the semester 1, 2 and 3 Rubric courses. Two 
respondents further stated that they had never attended the course but were only given exposure on the scoring and examination of the General Studies subject as well as the essay writing technique by paper examiner.

Interview Question 2: Do these Courses Emphasize the Use of I-Think Round Maps in Teaching Essay Writing of General Studies Subject?

For the second question, two teachers stated that the course they attended emphasized the use of a round map to improve student memory on the contents of a title. While three respondents stated that the use of round maps was not emphasized when they attended the course as the use of the i-Think map was still not applied and the use of the i-Think map took longer than conventional methods.

Interview Questions 3: Have Teachers Ever Attended Special Courses Regarding the Use of IThink Round Maps?

Based on the respondents' answers for the third question, it was found that three teachers did not attend special courses for the use of i-Think round maps. Meanwhile, a teacher attended a course on the i-Think maps several years ago and another attended a course explaining the use of all types of i-Think maps in general.

Interview 4: Please indicate if you have Ever Attended LADAP on I-Think Round Map and the Content of the Course

For the last question, two respondents stated that they had never attended LADAP on i-Think round maps. Meanwhile, three respondents attended LADAP on usage of i-Think map at the school level. Respondents who attended the course stated that the content of the course covers the use of $\mathrm{i}$-Think maps as well as the importance of using $\mathrm{i}$-Think maps in the learning process to encourage students to think.

\section{Conclusion}

Overall, it can be stated that teachers use the i-Think round maps to teach essay writing of General Studies subject to students. Most of the respondents stated that they use i-Think maps and idea discussion method to teach essay writings of General Studies subject. Teachers also know how to use i-Think round maps to teach students and the benefits of using them in the essay writing of General Studies subject. Most teachers use i-Think maps during presentation of ideas for essay writings and found out that using i-Think maps for teaching essay writing of General Studies subject is very effective. This proves that the use of round map is very effective to teach the essay writing of General Studies subject to Pre University students.

Furthermore, although the exposure given to teachers on the use of the i-Think round maps is still low, but teachers still use this method widely. This can indicate that the use of $i$-Think round maps is something that is easy to learn and apply by teachers. Therefore, it is hoped that through this study, more teachers will gain awareness about the use of a round- map in the essay writing of General Studies subject and other essays as well as its benefits. The researcher also 
encourages and recommend teachers to use i-Think maps to simplify the facts that students are supposed to remember or memorize.

\section{Acknowledgement}

We would like to extend our gratitude to the Faculty of Human Development, Research Management and Innovation Center (RMIC) for the University Research Grant (code: 2018-0232107-01) that helped fund the research. Human Resource Department of Sultan Idris Education University, Ministry of Education, Malaysia and Ministry of Higher Education (MOHE) for approving the grant to carry out this research and publish a journal.

\section{References}

Buzan, B., \& Buzan, T. (2003). The Mind Map Book. London: BBC Worldwide Limited. Hyerle, D., \& Yeager. (2007). Thinking Maps: A Language for Learning. US: Thinking Maps Inc. Hwa, T.G. (2004). Masalah Pembelajaran Sejarah: Satu Kajian Tindakan. Tesis Sarjana. Universiti Utara Malaysia.

Kementerian Pelajaran Malaysia. (2013). Pelan Pembangunan Pendidikan Malaysia, 2013 -2025. Malaysia: Putrajaya.

Loganathan, K. (1992). Hermeneutic analysis of discourse. Thiruvananthapuram: International School of Dravidian Linguistics.

Loganathan, K. (1996). Metaphysica universalis of meykandar. London: World Saiva Council.

Mueller, V. K. (1997). The hermeneutics reader. New York: The Continnum Publishing Company.

Rosli, M. M. \& Sidek, S. (2013). Innovation and firm performance: evidence from Malaysian small and medium enterprises. Paper presented at the 20th International Business Information Management Conference (IBIMA). International Business Information Management Association, pp. 794-809.

Sabar, S., \& Khalid, M. (2005). Kertas Konsep Faktor-faktor Graduan Berkerjaya Memilih Kursus Pengurusan Lepasan Ijazah-Pengkhususan Sekolah Rendah. Jurnal Penyelidikan MPBL.6: 35-52.

Suppiah, N. (2003). Proses kognitif dalam penulisan esei melalui analisis hermeneutik. Pulau Pinang: Universiti Sains Malaysia. Tesis Doktor Falsafah (tesis yang tidak diterbitkan).

Taha, M. (2004). Belajar Cara Mudah. Peningkatan Minda. Pusat Pengajian Umum Bangi: UKM. 